\title{
SISTEM INFORMASI GEOGRAFIS UNTUK ANALISA SPASIAL POTENSI LEMBAGA PENDIDIKAN KETERAMPILAN
}

\author{
Saefudin $^{1}$, Diki Susandi ${ }^{2}$ \\ Program Studi Sistem Informasi Fakultas Teknologi Informasi Universitas Serang Raya \\ Program Studi Informatika Fakultas Teknologi Informasi Universitas Serang Raya \\ Jln. Raya Cilegon Serang - Drangong Kota Serang \\ ${ }^{1}$ Saefudin12@gmail.com, \\ 2unsera.diky@gmail.com
}

\begin{abstract}
Abstrak - Sistem Informasi Geografis adalah sistem informasi yang digunakan untuk memasukkan, menyimpan, memanggil kembali, mengelola, menganalisa, dan menghasilkan data bereferensi geografis atau geospatial, untuk mendukung pengambilan keputusan dalam suatu perencanaan. Perpindahan Lembaga Pendidikan Keterampilan (LPK) "Mandiri" perlu analisis berbasis spasial dengan SIG. SIG merupakan suatu alat yang tepat untuk mengelola data spasial, SIG memungkinkan untuk analisis data tabulasi dan spasial secara cepat dan akurat. Dalam melakukan analisa spasial berbasis SIG akan dilakukan tahapan antara lain, digitasi ke data vektor dari image raster, pembuatan model kriteria analisa potensi dengan membandingkan antara potensi Lembaga Pendidikan Ketrerampilan lama dan Lembaga Keterampilan Pendidikan baru, pengumpulan data untuk dimasukan dalam database SIG, melakukan analisa proximity terhadap model kriteria, penentuan model strategi pengembangan dan memberikan rekomendasi dari hasil analisis. Analisa kebutuhan yang diperlukan untuk analisa spasial Potensi Lembaga Pendidikan Keterampilan "Mandiri" menggunakan pendekatan Zachman Framework. Sedangkan untuk melakukan perancangan sistem digunakan pemodelan desain sistem dengan menggunakan Unified Modeling Language (UML). Hasil analisis spasial berbasis SIG untuk lembaga baru diharapkan dapat membantu pihak manajemen untuk pembuatan roadmap pengembangan lembaga baru.
\end{abstract}

Kata Kunci - Sistem Informasi Geografis, Analisa Spasial, Framework Zachman, Buffer

\section{PENDAHULUAN}

Lembaga Pendidikan Keterampilan "MANDIRI" merupakan suatu lembaga pendidikan keterampilan seperti : Kursus komputer, Bahasa Inggris, Bahasa Arab, Akuntansi, bimbingan belajar untuk tingkat SD,SMP, SMA dan Umum. Saat ini perkembangannya sangat pesat, diantaranya meningkatnya jumlah siswa dari tahun ke tahun. Sehingga memerlukan perluasan lahan lembaga, maka telah diputuskan melakukan perpindahan pada tahun 2018 dari tempat lama. Hal ini tentunya merupakan tantangan bagi lembaga pendidikan untuk mengakomodir jumlah siswa kaitannya dengan fasilitas gedung yang tersedia, infrastruktur dan fasilitas penunjang lainnya.
Kondisi lahan di sekitar LPK saat ini tidak memungkinkan untuk dilakukan perluasan, karena penggunaan lahan di sekitar berupa permukiman, perkantoran, perdagangan dan jasa. Oleh karena itu diperlukan lokasi baru untuk pengembangan Lembaga Pendidikan Keterampilan "Mandiri". Namum dalam proses perpindahan tersebut belum pernah dilakukan analisis terhadap peluang atau potensi bidang pengembangan sehingga sampai saat ini lembaga pendidikan keterampilan "Mandiri" belum mempunyai petunjuk perencanaan atau roadmap untuk pengembangan tempat baru. Hal ini akan mengakibatkan pembangunan infrastruktur dan bidang lainnya menjadi tidak terarah. 
Oleh karena itu, diperlukan strategi pengembangan lembaga baru agar menjadi terarah dan dapat berkontribusi secara nasional. Saat ini perkembangan teknologi komunikasi dan informasi sangat cepat terutama sistem informasi geografis (SIG), maka untuk mendapatkan strategi pengembangan dengan berbasis spasial dengan SIG akan membantu pihak manajemen dalam menentukan strategi pengembangan lembaga pendidikan keterampilan baru "Mandiri"..

SIG merupakan suatu alat yang tepat untuk mengelola data spasial, SIG memungkinkan untuk analisis data tabulasi dan spasial secara cepat dan akurat. Dalam melakukan analisa spasial berbasis SIG akan dilakukan tahapan antara lain, digitasi ke data vektor dari image raster, pembuatan model kriteria analisa potensi dengan membandingkan antara potensi LPK lama dan LPK baru, pengumpulan data untuk dimasukan dalam database SIG, melakukan analisa proximity terhadap model kriteria, penentuan model strategi pengembangan dan memberikan rekomendasi dari hasil analisis.

Hasil analisis spasial berbasis SIG untuk pengembangan lembaga pendidikan keterampilan baru "Mandiri" diharapkan dapat membantu pihak manajemen untuk pembuatan roadmap pengembangan sehingga lembaga dapat memberikan kontribusi terhadap pengembangan sumber daya manusia di propinsi Banten dan Indonesia pada umunya.

\subsection{Sistem Informasi Geografis}

\section{DASAR TEORI}

Sistem Informasi Geografi (SIG) merupakan sistem informasi yang dirancang menggunakan basis data yang memiliki referensi spasial atau berkoordinat geografi. Sebagai suatu sistem yang berbasis komputer, paling tidak ada empat pendekatan yang bisa dipergunakan untuk mendefinisikan dan membagi SIG, yaitu pendekatan proses (process oriented), pendekatan kegunaan alat (toolbox approach), pendekatan data base (database approach) dan pendekatan aplikasi (application approach).

\subsection{Framework Zachman}

Framework Zachman adalah framework Arsitektur Enterprise yang menyediakan cara untuk memandang dan mendefinisikan sebuah enterprise secara formal dan terstruktur dengan baik. Framework ini terdiri atas matriks klasifikasi dua dimensi yang dibangun dari kombinasi beberapa pertanyaan umum yaitu What, Where, When, Why, Who dan How. Zachman Framework pertama kali diperkenalkan oleh John A Zachman pada tahun 1987 dan kemudian dikembangkan pada tahun 1992 dengan tujuan untuk menyediakan struktur dasar organisasi yang mendukung akses, integrasi, interpretasi, pengembangan, pengelolaan, dan perubahan perangkat arsitektural dari sistem informasi organisasi (enterprise).

\subsection{ArcView}

ArcView merupakan salah satu perangkat lunak desktop SIG dan pemetaan yang dikembangkan oleh ESRI (Environmental Systems Research Institute, Inc). Dengan perangkat lunak ini dapat melakukan proses-proses seperti visualisasi, meng-explore, menjawab query (baik basis data spasial maupun non spasial), dan menganalisa data geografis beserta atributnya. Beberapa kemampuan yang dimiliki ArcView diantarannya :

1. Pertukaran data, membaca dan menuliskan data dari dan ke dalam format perangkat lunak SIG lainnya.

2. Melalukan analisis statistik dan operasi-operasi matematis.

3. Menampilkan informasi (basisdata) spasial maupun atribut.

4. Menghubungkan informasi spasial dengan atribut-atributnya yang terdapat (disimpan) dalam basisdata atribut.

5. Melakukan fungsi-fungsi dasar SIG seperti analisis sederhana spasial.

6. Membuat peta tematik.

7. Meng-customize aplikasi dengan menggunakan bahasa skrip atau bahasa pemrograman sederhana.

8. Melakukan fungsi-fungsi SIG khusus lainnya (dengan menggunakan extension yang ditujukan untuk mendukung penggunaan perangkat lunak SIG ArcView).

\subsection{Unified Modeling Language}

Unified Modeling Language (UML) adalah bahasa pemodelan umum yang digunakan untuk melakukan spesifikasi, visualisasi, konstruksi dan dokumentasi artifact (bagian dari informasi yang digunakan atau dihasilkan oleh proses pembuatan perangkat lunak, artifact tersebut dapat berupa model, deskripsi atau perangkat lunak) dari sistem perangkat lunak. (Booch, Rumbaugh dan Jacobson, 1998: p3). UML menawarkan sebuah standar untuk merancang model sebuah sistem pengembangan perangkat lunak berbasis Object Oriented.

\subsection{Analisa Kebutuhan \\ 3.1.1 Analisa Kebutuhan Data}

\section{METODOLOGI PENELITIAN}

Untuk menganalisa kebutuhan digunakan pendekatan Zachman Framework untuk menganalisa kebutuhan data, kebutuhan proses dan konfigurasi jaringan komputer. Sedangkan untuk melakukan perancangan sistem dalam mengembangkan sistem informasi analisis spasial lembaga pendidikan keterampilan "Mandiri" digunakan pemodelan desain sistem dengan menggunakan UML..

Analisa kebutuhan data secara detail tercantum pada tabel berikut : 
Tabel 3.1

Hasil Analisis Kebutuhan Data Tabulasi

\begin{tabular}{|c|c|c|c|}
\hline No & Nama Data & Atribut Data & Jenis \\
\hline \multirow[t]{4}{*}{1} & \multirow[t]{4}{*}{ Jalan } & Kode Jalan & \multirow{4}{*}{$\begin{array}{l}\text { Jalan Utama } \\
\text { Jalan Kota } \\
\text { Jalan Kampung } \\
\text { Jalan Komplek } \\
\text { Perumahan }\end{array}$} \\
\hline & & Jenis Jalan & \\
\hline & & Nama Jalan & \\
\hline & & Panjang Jalan & \\
\hline \multirow[t]{3}{*}{2} & \multirow[t]{3}{*}{ Rute Kendaraan } & Kode Rute & \multirow{3}{*}{$\begin{array}{l}\text { Angkot } \\
\text { Bus }\end{array}$} \\
\hline & & $\begin{array}{l}\text { Jenis Rute } \\
\text { Kendaraan }\end{array}$ & \\
\hline & & $\begin{array}{l}\text { Banyaknya Rute } \\
\text { Kendaraan }\end{array}$ & \\
\hline \multirow[t]{3}{*}{3.} & \multirow[t]{3}{*}{ Tempat Tinggal } & $\begin{array}{ll}\text { Id } & \text { tempat } \\
\text { tinggal } & \\
\end{array}$ & \multirow{3}{*}{$\begin{array}{l}\text { Rumah tinggal } \\
\text { Rumah Kos } \\
\text { Perumahan }\end{array}$} \\
\hline & & $\begin{array}{ll}\text { Jenis } & \text { tempat } \\
\text { tinggal } & \end{array}$ & \\
\hline & & $\begin{array}{l}\text { Kode wilayah } \\
\text { tempat tinggal }\end{array}$ & \\
\hline \multirow[t]{3}{*}{4.} & \multirow[t]{3}{*}{ Pusat Bisnis } & Id Pusat Bisnis & \multirow{3}{*}{$\begin{array}{l}\text { Pusat Perbelanjaan } \\
\text { Perkantoran Swasta } \\
\text { Perkantoran } \\
\text { Pemerintah }\end{array}$} \\
\hline & & $\begin{array}{ll}\text { Jenis } & \text { Pusat } \\
\text { Bisnis } & \\
\end{array}$ & \\
\hline & & $\begin{array}{lr}\text { Kode } & \text { wilayah } \\
\text { pusat } & \text { bisnis }\end{array}$ & \\
\hline \multirow[t]{3}{*}{5.} & \multirow[t]{3}{*}{ Fasilitas Umum } & $\begin{array}{ll}\text { Id } & \text { fasilitas } \\
\text { umum } & \end{array}$ & \multirow{3}{*}{$\begin{array}{l}\text { Mini Market } \\
\text { Warnet } \\
\text { Fotocopy } \\
\text { Warung Makan } \\
\text { Toko ATK } \\
\text { Restoran }\end{array}$} \\
\hline & & $\begin{array}{l}\text { Jenis Fasilitas } \\
\text { Umum }\end{array}$ & \\
\hline & & $\begin{array}{l}\text { Kode Wilayah } \\
\text { fasilitas umum }\end{array}$ & \\
\hline \multirow[t]{3}{*}{6.} & \multirow[t]{3}{*}{ Pusat Kesehatan } & $\begin{array}{ll}\text { id } & \text { Pusat } \\
\text { kesehatan } & \end{array}$ & \multirow[t]{3}{*}{$\begin{array}{l}\text { Rumah Sakit } \\
\text { Puskesmas }\end{array}$} \\
\hline & & Jenis Kesehatan & \\
\hline & & Kode kesehatan & \\
\hline
\end{tabular}

Analisa kebutuhan data keruangan (spasial) secara detail tercantum pada tabel berikut :

Tabel 3.2

Hasil Analisis Kebutuhan Data Keruangan (Spasial)

\begin{tabular}{|c|c|c|c|}
\hline No & Nama Data & $\begin{array}{c}\text { Representatif } \\
\text { Data }\end{array}$ & Deskripsi \\
\hline 1 & $\begin{array}{l}\text { Titik } \\
\text { (Data } \\
\text { Spasial } \\
\text { Vektor) }\end{array}$ & $\begin{array}{l}\text { Foto Copy } \\
\text { Toko ATK } \\
\text { Rumah kos } \\
\text { Warung Makan } \\
\text { Warnet } \\
\text { Rumah sakit } \\
\text { Puskesmas } \\
\text { Mini Market } \\
\text { Restoran }\end{array}$ & $\begin{array}{lr}\text { Titik merupakan } \\
\text { representasi } & \text { grafis } \\
\text { yang } & \text { paling } \\
\text { sederhana pada } & \text { suatu } \\
\text { obyek. Titik tidak } \\
\text { mempunyai dimensi } \\
\text { tetapi } \\
\text { ditampilkan dalam } \\
\text { bentuk simbol baik } \\
\text { pada peta maupun } \\
\text { dalam layar monitor }\end{array}$ \\
\hline 2 & $\begin{array}{l}\text { Garis } \\
\text { (Data } \\
\text { Spasial } \\
\text { Vektor) }\end{array}$ & $\begin{array}{l}\text { Jalan Utama } \\
\text { Jalan Kota } \\
\text { Jalan } \\
\text { Perumahan/kompl } \\
\text { ek } \\
\text { Jalan Kampung }\end{array}$ & $\begin{array}{l}\text { Garis merupakan } \\
\text { bentuk linear yang } \\
\text { menghubungkan dua } \\
\text { atau lebih titik dan } \\
\text { merepresentasikan } \\
\text { obyek dalam satu } \\
\text { dimensi. }\end{array}$ \\
\hline 3 & $\begin{array}{l}\text { Polygon } \\
\text { (Data } \\
\text { Spasial } \\
\text { Vektor) }\end{array}$ & $\begin{array}{l}\text { Wilayah } \\
\text { Perumahan } \\
\text { Pemukiman } \\
\text { Penduduk } \\
\text { Perkantoran } \\
\text { swasta } \\
\text { Perkantoran } \\
\text { Pemerintah } \\
\text { Pusat } \\
\text { Perbelanjaan }\end{array}$ & $\begin{array}{l}\text { Poligon merupakan } \\
\text { representasi obyek } \\
\text { dalam dua dimensi }\end{array}$ \\
\hline 4 & $\begin{array}{l}\text { Peta Digital } \\
\text { Google } \\
\text { Earth (Data } \\
\text { Spasil } \\
\text { Raster) }\end{array}$ & $\begin{array}{l}\text { Wilayah Lembaga } \\
\text { Pendidikan } \\
\text { Keterampilan } \\
\text { Baru "Mandiri" } \\
\text { Wilayah Lembaga } \\
\text { Pendidikan } \\
\text { Keterampilan } \\
\text { "Mandiri" Baru }\end{array}$ & $\begin{array}{l}\text { Google } \\
\text { adalah sebuah } \\
\text { aplikasi } \\
\text { yang menyediakan du } \\
\text { nia virtual, peta dan } \\
\text { informasi } \\
\text { geografis dapat } \\
\text { digunakan } \\
\text { untuk perjalanan } \\
\text { atau,melihat } \\
\text { gambar, bangunan } \\
\text { 3D, peta dan lainnya. }\end{array}$ \\
\hline
\end{tabular}

\subsubsection{Analisa Kebutuhan Proses}

Proses yang dibutuhkan untuk Analisa Spasial Potensi Lembaga Pendidikan Keterampilan (Mandiri) berbasis sistem informasi geografis adalah :

Tabel 3.3

Analisa Kebutuhan Proses

\begin{tabular}{|c|c|c|c|c|}
\hline No & $\begin{array}{l}\text { Nama } \\
\text { Proses }\end{array}$ & $\begin{array}{l}\text { Uraian } \\
\text { Proses }\end{array}$ & Data Input & $\begin{array}{c}\text { Aktor } \\
\text { /User }\end{array}$ \\
\hline
\end{tabular}




\begin{tabular}{|c|c|c|c|c|}
\hline 1 & $\begin{array}{l}\text { Pengelola } \\
\text { an View }\end{array}$ & $\begin{array}{l}\text { Proses ini } \\
\text { dilakukan } \\
\text { oleh aktor } \\
\text { dan terdiri } \\
\text { dari } \\
\text { penambaha, } \\
\text { perbaikan, } \\
\text { hapus dan } \\
\text { simpan } \\
\text { untuk } \\
\text { digitasi }\end{array}$ & $\begin{array}{l}\text { Input: } \\
\text { Layer View } \\
\text { Output : } \\
\text { Tampilan } \\
\text { layer }\end{array}$ & Aktor \\
\hline 2 & $\begin{array}{l}\text { Pengelola } \\
\text { an Theme }\end{array}$ & $\begin{array}{l}\text { Proses ini } \\
\text { dilakukan } \\
\text { oleh aktor } \\
\text { dan terdiri } \\
\text { dari } \\
\text { penambahan } \\
\text {, perbaikan, } \\
\text { hapus dan } \\
\text { simpan } \\
\text { untuk data } \\
\text { keruangan } \\
\text { titik, garis } \\
\text { dan polygon }\end{array}$ & $\begin{array}{l}\text { Input: } \\
\text { Layer data } \\
\text { grafis } \\
\text { Output : } \\
\text { Tampilan } \\
\text { layer grafis }\end{array}$ & Aktor \\
\hline 3 & $\begin{array}{l}\text { Pengelola } \\
\text { an Data } \\
\text { Tabulasi }\end{array}$ & $\begin{array}{l}\text { Proses ini } \\
\text { dilakukan } \\
\text { oleh peneliti } \\
\text { untuk } \\
\text { update dan } \\
\text { menyimpan } \\
\text { atribut data } \\
\text { spasial titik, } \\
\text { garis dan } \\
\text { poligon } \\
\text { yang } \\
\text { meliputi } \\
\text { ruas jalan, } \\
\text { wilayah } \\
\text { perumahan, } \\
\text { wilayah kos, } \\
\text { pemukiman } \\
\text { penduduk, } \\
\text { tempat } \\
\text { usaha, } \\
\text { perkantoran, } \\
\text { fasilitas } \\
\text { umum }\end{array}$ & $\begin{array}{l}\text { Input: } \\
\text { Layer view } \\
\text { Output : } \\
\text { Data ruas } \\
\text { jalan, data } \\
\text { perumahan, } \\
\text { data rumah } \\
\text { kos, data } \\
\text { pemukiman, } \\
\text { data tempat } \\
\text { usaha, data } \\
\text { fasilitas } \\
\text { umum }\end{array}$ & Aktor \\
\hline 5 & $\begin{array}{l}\text { Analisis } \\
\text { Potensi } \\
\text { Lembaga }\end{array}$ & $\begin{array}{l}\text { Dalam } \\
\text { proses ini } \\
\text { akan } \\
\text { dilakukan } \\
\text { analisis } \\
\text { untuk mendapatka } \\
\text { n nilai } \\
\text { prioritas }\end{array}$ & Input : & Aktor \\
\hline
\end{tabular}

\begin{tabular}{|c|c|c|c|c|}
\hline & & $\begin{array}{l}\text { lokal, } \\
\text { kemudian } \\
\text { setelah } \\
\text { semua } \\
\text { kriteria } \\
\text { sudah terisi, } \\
\text { maka akan } \\
\text { dilakukan } \\
\text { analisis } \\
\text { sesuai } \\
\text { dengan } \\
\text { kriteria } \\
\text { dengan } \\
\text { memberikan } \\
\text { penilian } \\
\text { dengan } \\
\text { standar yang } \\
\text { telah } \\
\text { ditentukan, } \\
\text { sehingga } \\
\text { pada akhir } \\
\text { proses ini } \\
\text { akan } \\
\text { didapatkan } \\
\text { hasil pilihan } \\
\text { yang tepat, } \\
\text { yang sesuai } \\
\text { dengan data } \\
\text { yang ada, } \\
\text { yang dapat } \\
\text { dilihat dari } \\
\text { persentase } \\
\text { yang } \\
\text { terbesar } \\
\text { pada } \\
\text { prioritas } \\
\text { global }\end{array}$ & & \\
\hline 6 & $\begin{array}{l}\text { Laporan } \\
\text { Hasil } \\
\text { Analisis }\end{array}$ & $\begin{array}{l}\text { Proses ini } \\
\text { dilakukan } \\
\text { oleh aktor } \\
\text { dan } \\
\text { Manajemen } \\
\text { dari hasil } \\
\text { analisis } \\
\text { yang } \\
\text { dilaporkan } \\
\text { berupa } \\
\text { layout. }\end{array}$ & $\begin{array}{l}\text { Input : } \\
\text { Data } \\
\text { analisis } \\
\text { Output : } \\
\text { Hasil } \\
\text { analisis }\end{array}$ & $\begin{array}{l}\text { Aktor/Ma } \\
\text { najemen } \\
\text { lembaga }\end{array}$ \\
\hline
\end{tabular}

\subsubsection{Analisa Kebutuhan Perangkat}

\section{a. Analisa Kebutuhan Perangkat Lunak}

Perangkat lunak digunakan untuk melakukan proses menyimpan, menganalisa, memvisualkan data-data baik data spasial maupun non-spasial. Analisa kebutuhan perangkat lunak secara detail tercantum pada tabel berikut : 
Tabel 3.4

Analisa Kebutuhan Perangkat Lunak

\begin{tabular}{|c|l|c|}
\hline No & \multicolumn{1}{|c|}{ Nama Perangkat Lunak } & Fungsi \\
\hline 1. & Windows 7 & Sistem Operasi \\
\hline 2. & Arcview versi 3.30 & GIS Software \\
\hline 3. & Mozilla Firefox & Web Browser \\
\hline 4. & Geogle Earth & Image Raster \\
\hline
\end{tabular}

\section{b. Analisa Kebutuhan Perangkat Keras}

Perangkat keras yang digunakan harus dapat mendukung perangkat lunak untuk membangun sistem. Perangkat keras yang digunakan adalah sebagai berikut:

Tabel 3.5

\section{Analisa Kebutuhan Perangkat Keras}

\begin{tabular}{|c|l|lc|}
\hline No & Nama Perangkat & \multicolumn{2}{|c|}{ Spesifikasi } \\
\hline 1. & Komputer & Processor & $:$ AMD Athlon X2 \\
& & & 7750 2,7 GHZ \\
& & Monitor & $:$ Monitor LCD \\
& & Samsung 17', \\
& & Hard Disk & $:$ WDC 320 GB \\
& & RAM & $:$ 2 GB DDR II \\
& VGA & $:$ GForce 8600 256 \\
& & MB 128 Bit f. \\
& & Mouse & $:$ PS2 \\
& & Keyboard & $:$ 104 Key \\
& & Printer & : HP F2276 (Print, \\
& & & Scan dan Copy ) \\
\hline
\end{tabular}

\subsection{Perancangan Penelitian}

\subsubsection{Model Bisnis}

Setelah selesai pada tahap analisa kebutuhan, maka tahap berikutnya adalah menterjemahkan hasil analisa ke dalam bentuk model salah satu diagram yaitu use case diagram untuk menjelaskan gambaran sistem dan aktor yang terlibat secara keseluruhan.

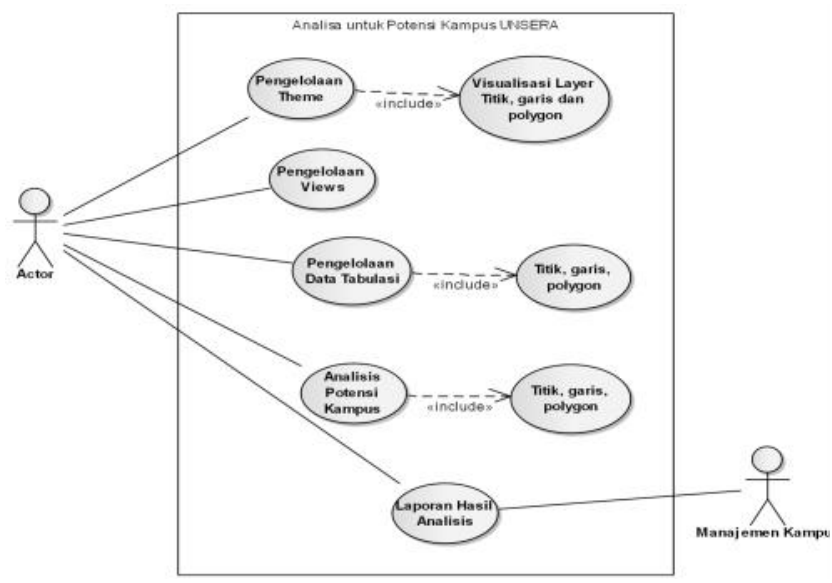

\section{Gambar 3.1}

Use Case Diagram

\subsection{Perancangan Tampilan dan Tabulasi \\ a. Tampilan Menu Utama}

Pada menu utama ini akan ditampilkan beberapa menu pilihan diantaranya: menu view, menu theme, menu tabulasi, menu analisis dan menu laporan.

Pada rancangan menu analisa terdiri dari analisa ring 1, ring 2 dan ring 3 . Analisa setiap ring mencakup beberapa analisa titik, garis dan polygon. Berikut tampilan analis ring.

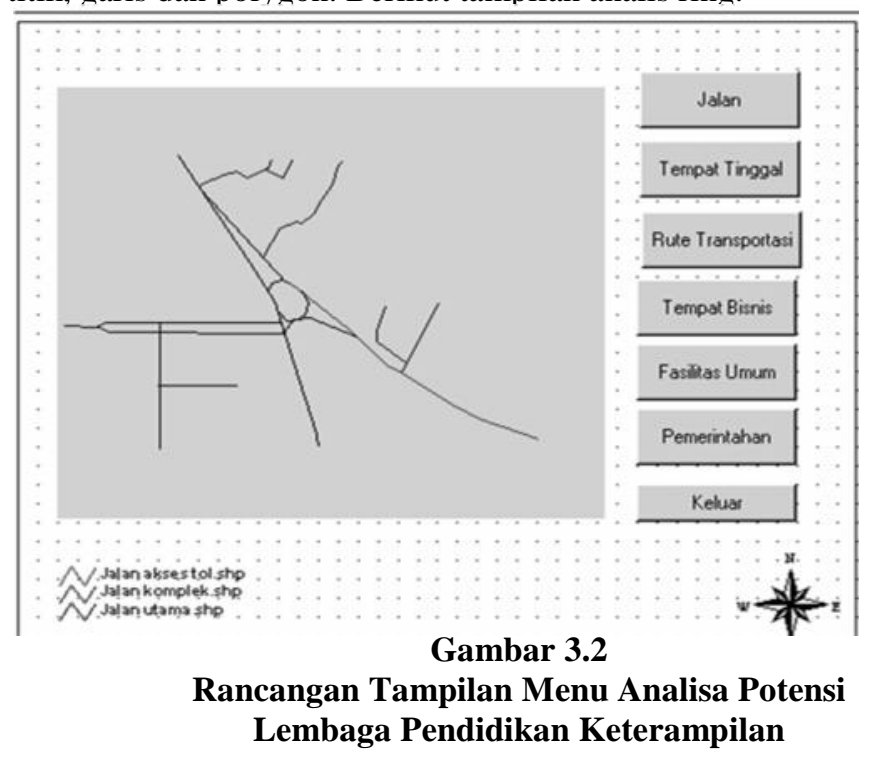

\section{b. Rancangan Tabulasi}

Tabulasi jalan utama

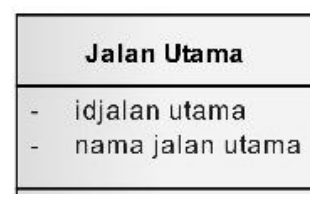

Tabulasi jalan perumahan

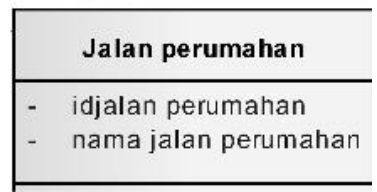

Tabulasi Perk Swasta

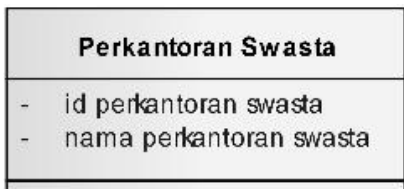

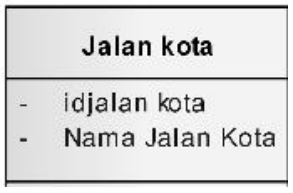

Tabulasi Toko ATK

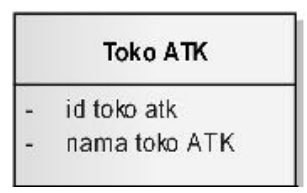

Tabulasi Warnet

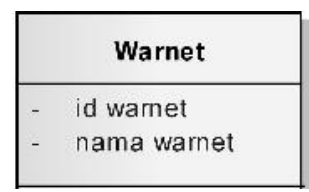

Tabulasi Jalan Kota 
Tabulasi Tempat Usaha

\begin{tabular}{|ll|}
\hline \multicolumn{1}{|c|}{ foto copy } \\
\hline- & id foto copy \\
- & nama foto copy \\
\hline
\end{tabular}

Tabulasi Jalan Kampung

\begin{tabular}{|l|}
\hline \multicolumn{1}{|c|}{ Jalan Kampung } \\
\hline$-\quad$ id jalan kampung \\
$-\quad$ nama jalan kampung \\
\hline
\end{tabular}

Gambar 3.25

Rancangan Tabulasi

\subsection{Teknik Analisis}

Teknik analisis yang dilakukan berupa metode buffering dengan membuat suatu ring yang berpusat pada wilayah LPK melebar ke wilayah diluar LPK dengan menggunakan tools yang ada dalam arcview.

Ring merupakan suatu lingkaran yang mempunyai jarijari tertentu berupa suatu jarak dimana pusatnya berada diwilayah LPK, selanjutnya akan dihitung objek-objek yang berada dalam suatu ring. Objek-objek akan dijumlahkan dan kemudian dibandingkan antara lembaga lama dan lembaga baru. Kesimpulan yang diperoleh untuk analisa spasial potensi lembaga pendidikan keterampilan Mandiri dengan memberkan nilai skor pada setiap perbandingan hasil analisis antara lembaga lama dan lembaga baru yang ditunjukkan pada tabel berikut :

Tabel 3.6

Kriteria Nilai LPK Lama

\begin{tabular}{|c|c|c|c|c|c|c|c|c|}
\hline & \multirow{4}{*}{$\begin{array}{l}\text { Parameter } \\
\text { Jalan }\end{array}$} & \multicolumn{6}{|c|}{ 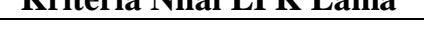 } & \\
\hline \multirow{3}{*}{$\begin{array}{l}\mathbf{N} \\
\mathbf{o} \\
1\end{array}$} & & \multicolumn{6}{|c|}{ Jumlah dan Nilai } & \multirow{2}{*}{$\begin{array}{l}\text { Nilai } \\
\text { Total }\end{array}$} \\
\hline & & \multicolumn{2}{|c|}{$\begin{array}{c}\text { Ring I } \\
(1-2 K M)\end{array}$} & \multicolumn{2}{|c|}{$\begin{array}{c}\text { Ring II } \\
(2-3 \mathrm{Km})\end{array}$} & \multicolumn{2}{|c|}{$\underset{(3-5 \mathrm{Km})}{\text { Ring III }}$} & \\
\hline & & 2 & 3 & 2 & 2 & 3 & 1 & 13 \\
\hline 2 & Rute Kendaraan & 3 & 3 & 1 & 2 & 3 & 1 & 14 \\
\hline 3 & Tempat Tinggal & 6 & 3 & 2 & 2 & 1 & 1 & 23 \\
\hline 4 & Pusat Bisnis & 8 & 3 & 4 & 2 & 5 & 1 & 37 \\
\hline 5 & Fasilitas Umum & 2 & 3 & 6 & 2 & 8 & 1 & 27 \\
\hline \multirow[t]{2}{*}{6} & Pusat Kesehatan & 2 & 3 & 5 & 2 & 5 & 1 & 21 \\
\hline & \multicolumn{7}{|c|}{ Jumlah } & 134 \\
\hline
\end{tabular}

Tabel 3.7

Kriteria Nilai LPK Baru

\begin{tabular}{|c|c|c|c|c|c|c|c|c|}
\hline \multirow{3}{*}{$\begin{array}{l}\mathbf{N} \\
\mathbf{0} \\
1\end{array}$} & \multirow{3}{*}{$\begin{array}{l}\text { Parameter } \\
\text { Jalan }\end{array}$} & \multicolumn{6}{|c|}{ Jumlah dan Nilai } & \multirow{3}{*}{$\begin{array}{c}\text { Nilai } \\
\text { Total } \\
10\end{array}$} \\
\hline & & \multicolumn{2}{|c|}{$\begin{array}{c}\text { Ring I } \\
(1-2 \text { KM) }\end{array}$} & \multicolumn{2}{|c|}{$\begin{array}{c}\text { Ring II } \\
(2-3 \mathrm{Km})\end{array}$} & \multicolumn{2}{|c|}{$\begin{array}{c}\text { Ring III } \\
(3-5 \mathrm{Km})\end{array}$} & \\
\hline & & 1 & 3 & 2 & 2 & 3 & 1 & \\
\hline 2 & Rute Kendaraan & 1 & 3 & 1 & 2 & 1 & 1 & 6 \\
\hline 3 & Tempat Tinggal & 2 & 3 & 2 & 2 & 1 & 1 & 11 \\
\hline 4 & Pusat Bisnis & 4 & 3 & 4 & 2 & 5 & 1 & 25 \\
\hline 5 & Fasilitas Umum & 2 & 3 & 6 & 2 & 4 & 1 & 16 \\
\hline \multirow[t]{2}{*}{6} & Pusat Kesehatan & 1 & 3 & 5 & 2 & 5 & 1 & 18 \\
\hline & \multicolumn{7}{|c|}{ Jumlah } & 89 \\
\hline
\end{tabular}

Berdasarkan dua tabel analisis potensi antara LPK lama dan LPK baru dibandingkan bila hasil total perhitungan mempunyai nilai lebih besar maka dikatakan bahwa LPK tersebut memiliki potensi yang lebih baik.

\section{Hasil dan Pembahasan \\ 4.1 Hasil Analisa Spasial}

Hasil analisa spasial akan ditunjukan jumlah objek pada masing-masing analisis. Metode analisis yang digunakan adalah buffering dengan kriteria ditunjukan pada tabel berikut :

Tabel 4.1

Jarak Ring

\begin{tabular}{|c|c|c|}
\hline No & Ring & Jarak (jari-jari) \\
\hline 1 & 1 & $0-1 \mathrm{Km}$ \\
2 & 2 & $1-2 \mathrm{Km}$ \\
3 & 3 & $2-4 \mathrm{Km}$ \\
\hline
\end{tabular}

Untuk masing-masing objek titik, garis dan polygon didapatkan hasil analisis buffering untuk LPK lama sebagai berikut :

Tabel 4.2

Hasil Analisis Nilai Potensi LPK Lama

\begin{tabular}{|c|c|c|c|c|}
\hline No & Ring & Titik & Garis & Polygon \\
\hline 1 & 1 & 180 & 75 & 60 \\
2 & 2 & 44 & 48 & 51 \\
3 & 3 & 41 & 21 & 29 \\
\hline \multicolumn{2}{|c|}{ Jumlah } & 265 & 144 & 140 \\
\hline
\end{tabular}

Tabel 4.2 menerangkan tentang analisis untuk nilai potensi pada LPK lama berdasarkan tabel 3.6. Adapun arti dari tabel tersebut untuk ring I dengan nilai 180 untuk objek titik adalah jumlah ditentukan 60 sedangkan nilai bobot 3 .

Sedangkan untuk LPK baru diperoleh hasil analisis buffering sebagai berikut :

Tabel 4.3

Hasil Analisis Nilai Potensi LPK Baru

\begin{tabular}{|c|c|c|c|c|}
\hline No & Ring & Titik & Garis & Polygon \\
\hline 1 & 1 & 42 & 18 & 36 \\
2 & 2 & 30 & 20 & 15 \\
3 & 3 & 87 & 15 & 42 \\
\hline \multicolumn{2}{|c|}{ Jumlah } & 213 & 53 & 93 \\
\hline
\end{tabular}

Berdasarkan tabel ke 2 diatas ditunjukan bahwaLPK lama dibandingkan LPK baru masih tinggi potensinya LPK lama. Hal ini dibuktikan dengan nilai potensinya selalu lebih besar baik untuk objek titik (265:213), garis (144:53), dan polygon (140:93). 
Adapun rincian hasil analisis masing-masing objek per ring ditunjukan pada tabel berikut.

- Analisis Buffering Ring I untuk objek Titik

Tabel 4.4

Hasil Analisis Objek Titik Ring 1

\begin{tabular}{|c|l|c|c|}
\hline No & \multicolumn{1}{|c|}{ Nama Objek } & LPK Lama & LPK Baru \\
\hline 1 & Foto Copy & 15 & 2 \\
2 & Toko ATK & 4 & 1 \\
3 & Rumah Kos & 8 & 4 \\
4 & Warung Makan & 13 & 4 \\
5 & Warnet & 7 & 1 \\
6 & Mini Market & 1 & 1 \\
7 & Rumah Sakit & 1 & 0 \\
8 & Puskesmas & 2 & 0 \\
9 & Restoran & 60 & 1 \\
\hline
\end{tabular}

- Analisis Buffering Ring II untuk objek Titik

Tabel 4.5

Hasil Analisis Objek Titik Ring 2

\begin{tabular}{|c|l|c|c|}
\hline No & Nama Objek & LPK Lama & LPK Baru \\
\hline 1 & Foto Copy & 0 & 2 \\
2 & Toko ATK & 4 & 0 \\
3 & Rumah Kos & 2 & 5 \\
4 & Warung Makan & 6 & 3 \\
5 & Warnet & 3 & 1 \\
6 & Mini Market & 3 & 3 \\
7 & Rumah Sakit & 2 & 0 \\
8 & Puskesmas & 0 & 0 \\
9 & Restoran & 2 & 1 \\
\hline \multicolumn{2}{|c}{ Jumlah } & 22 & 15 \\
\hline
\end{tabular}

- Analisis Buffering Ring III untuk objek Titik

Tabel 4.6

Hasil Analisis Objek Titik Ring 3

\begin{tabular}{|c|l|c|c|}
\hline No & Nama Objek & LPK Lama & LPK Baru \\
\hline 1 & Foto Copy & 4 & 18 \\
2 & Toko ATK & 2 & 9 \\
3 & Rumah Kos & 8 & 12 \\
4 & Warung Makan & 7 & 17 \\
5 & Warnet & 4 & 12 \\
6 & Mini Market & 9 & 14 \\
7 & Rumah Sakit & 1 & 1 \\
8 & Puskesmas & 2 & 2 \\
9 & Restoran & 4 & 3 \\
\hline \multicolumn{2}{|c|}{ Jumlah } & 41 & 87 \\
\hline
\end{tabular}

- Analisis Buffering Ring I untuk objek Garis

Tabel 4.7
Hasil Analisis Objek Garis Ring 1

\begin{tabular}{|c|l|c|c|}
\hline No & Nama Objek & LPK Lama & LPK Baru \\
\hline 1 & Jalan Utama & 6 & 1 \\
2 & Jalan Kota & 10 & 1 \\
3 & Rute Bus & 2 & 1 \\
4 & Rute Angkot & 3 & 1 \\
\hline \multicolumn{2}{|c|}{ Jumlah } & 21 & 4 \\
\hline
\end{tabular}

- $\quad$ Analisis Ring II untuk objek Garis

Tabel 4.8

Hasil Analisis Objek Garis Ring 2

\begin{tabular}{|c|l|c|c|}
\hline No & Nama Objek & LPK Lama & LPK Baru \\
\hline 1 & Jalan Utama & 5 & 1 \\
2 & Jalan Kota & 7 & 1 \\
3 & Rute Bus & 1 & 1 \\
4 & Rute Angkot & 2 & 1 \\
\hline \multicolumn{2}{|c|}{ Jumlah } & 14 & 4 \\
\hline
\end{tabular}

- Analisis Ring III untuk objek Garis

Tabel 4.9

Hasil Analisis Objek Garis Ring 3

\begin{tabular}{|c|l|c|c|}
\hline No & Nama Objek & LPK Lama & LPK Baru \\
\hline 1 & Jalan Utama & 2 & 1 \\
2 & Jalan Kota & 6 & 5 \\
3 & Rute Bus & 1 & 1 \\
4 & Rute Angkot & 3 & 2 \\
\hline \multicolumn{2}{|c|}{ Jumlah } & 12 & 9 \\
\hline
\end{tabular}

- Analisis Ring I untuk objek Polygon

Tabel 4.10

Hasil Analisis Objek Polygon Ring 1

\begin{tabular}{|c|l|c|c|}
\hline No & \multicolumn{1}{|c|}{ Nama Objek } & LPK Lama & LPK Baru \\
\hline 1 & Tempat Tinggal & 5 & 1 \\
2 & Perumahan & 3 & 2 \\
3 & Mall & 1 & 0 \\
4 & Perkantoran Pemerintah & 8 & 1 \\
5 & Perkantoran Swasta & 4 & 1 \\
\hline \multicolumn{2}{|r|}{ Jumlah } & 21 & 5 \\
\hline
\end{tabular}

- Analisis Ring II untuk objek Polygon

Tabel 4.11

Hasil Analisis Objek Polygon Ring 2

\begin{tabular}{|c|l|c|c|}
\hline No & \multicolumn{1}{|c|}{ Nama Objek } & LPK Lama & $\begin{array}{c}\text { LPK } \\
\text { Baru }\end{array}$ \\
\hline 1 & Tempat Tinggal & 11 & 8 \\
2 & Perumahan & 4 & 4 \\
3 & Mall & 3 & 0 \\
4 & Perkantoran Pemerintah & 3 & 0 \\
5 & Perkantoran Swasta & 5 & 1 \\
\hline & Jumlah & 26 & 13 \\
\hline
\end{tabular}


- $\quad$ Analisis Ring III untuk objek Polygon

Tabel 4.12

Hasil Analisis Objek Polygon Ring 3

\begin{tabular}{|c|l|c|c|}
\hline No & \multicolumn{1}{|c|}{ Nama Objek } & LPK Lama & LPK Baru \\
\hline 1 & Tempat Tinggal & 14 & 23 \\
2 & Perumahan & 11 & 9 \\
3 & Mall & 2 & 3 \\
4 & Perkantoran Pemerintah & 2 & 5 \\
5 & Perkantoran Swasta & 2 & 5 \\
\hline \multicolumn{2}{r|}{ Jumlah } & 31 & 45 \\
\hline
\end{tabular}

\subsection{Pembahasan}

Berdasarkan hasil analisa spasial ternyata LPK lama lebih berpotensi daripada LPK Baru. Adapun parameter dalam rekomendasi ini tidak semuanya hanya yang bisa diimplementasikan dengan sejumlah sebanyak 5 parameter. Hal tersebut ditunjukan tabel sebagai berikut :

Tabel 4.13

Rekomendasi Hasil Analisis

\begin{tabular}{|c|l|c|c|c|}
\hline No & \multicolumn{1}{|c|}{ Parameter } & $\begin{array}{c}\text { LPK } \\
\text { Lama }\end{array}$ & $\begin{array}{c}\text { LPK } \\
\text { Baru }\end{array}$ & Deviasi \\
\hline 1 & Tempat Tinggal & & & \\
& - Rumah Kos & 37 & 34 & 3 \\
& Fasilitas Umum & & & \\
& - Foto Copy & 53 & 28 & 25 \\
& - Toko ATK & 22 & 10 & 12 \\
& - Warung Makan & 58 & 35 & 23 \\
& - Warnet & 31 & 17 & 14 \\
\hline
\end{tabular}

Agar LPK baru mempunyai potensi yang baik maka yang perlu dikembangkan untuk fasilitas umum perlu dibangun fasilitas-fasilitas seperti foto copy, toko atk, kantin dan warnet yang berada diwilayah sekitar LPK atau dalam LPK..

\subsection{Kesimpulan}

\section{KESIMPULAN}

Dari hasil penelitian yang dilakukan mulai dari tahap awal hingga proses analisis dapat disimpulkan bahwa dengan dilakukannya analisa spasial potensi lembaga MANDIRI berbasis Sistem Informasi Geografis maka dapat disimpulkan sebagai berikut:

a. Analisis potensi pengembangan lembaga baru MANDIRI menggunakan analisa spasial berbasis sistem informasi geografis dengan metode buffering dengan membuat suatu ring yang berpusat pada wilayah LPK melebar ke wilayah diluar LPK dengan menggunakan tools yang ada dalam arcview. b. Analisis spasial potensi LPK MANDIRI dapat membantu memberikan dukungan pengambil keputusan bagi manajemen LPK dalam pengembangan LPK MANDIRI dimasa yang akan datang.

5.2 Saran

Berdasarkan hasil penelitian, analisis spasial pontensi LPK baru MANDIRI dapat memberikan dukungan pengambilan keputusan bagi manajemen lembaga untuk pengembangan lembaga masa yang akan datang, namun terdapat beberapa hal yang perlu disarankan antara lain.

a. Melihat potensi lembaga baru kurang berpotensi daripada lembaga lama, maka pihak manajemen perlu membangun beberapa fasilitas seperti tempat tinggal dan fasilitas umum dalam kawasan lembaga sehingga dapat membantu memperlancar dalam kegiatan proses belajar siswa.

b. Pihak manajemen lembaga perlu melakukan potensi-potensi yang perlu dikembangkan dalam rangka promosi MANDIRI ke berbagai masyarakat

\section{REFERENSI}

[1] Awaludin, Nur., (2010) Principles, Techniques, Applications, and Management, Geogrphical Information System With ArcGIS 9.X, Andi, Jogjakarta, 2010.

[2] Budiyanto, Eko., (2007), Avenue Untuk Pengembangan Sistem Informasi Geografis, Andi, Jogjakarta, 2007.

[3] Budiyanto, Eko., (2009), Sistem Informasi dengan ArcView GIS, Andi, Jogjakarta, 2009.

[4] Dwi Arisa, Yoanita, (2009), Aplikasi GIS untuk Mencari Lokasi Cabang Warung Bu Kris Baru, Buku Tugas Akhir, Jurusan Teknologi Informasi PENS-ITS, Surabaya, 2009.

[5] GIS Konsorsium Aceh Nias, (2007), "Modul Pelatihan ArcGIS Tingkat Dasar", Banda Aceh, 2007.

[6] Keele, (1997). An Introduction to GIS using ArcView : Tutorial, Issue 1, Spring 1997 based on Arcview release 3, http://www.keele.ac.uk/depts/cc/helpdesk/arcview/av_prfc. htm

[7] Nuarsa, Wayan., (2005), Menganalisa Data Spasial dengan ArcView GIS 3.3, Penerbit Informatika, Bandung, 2005.

[8] Prahasta, Eddy.,(2001), Konsep-konsep Dasar Sistem Informasi Geografis, Informatika, Bandung, 2001.

[9] Prahasta, Eddy.,(2004), Sistem Informasi Geografis Tods \& Plugin, Informatika, Bandung, 2004.

[10] Prahasta, Eddy., (2009), Tutorial ArcVIew, Sistem Informasi Geografis, Informatika, Bandung, 2009. 
[11] Rosmantyo, Windhy Rokhmat, (2008), Aplikasi SIG Berbasis Web untuk Visualisasi Dampak Bencana Lumpur Sidoarjo, Buku Tugas Akhir Jurusan Teknologi Informasi PENS-ITS, Surabay, 2008.

[12] Tuman, (2001). "Overview of GIS", Http://www.gisdevelopment.net/tutorials/ tuman006.htm. 